\title{
THE GORBATCHEV BANG AND REGIONALIZATION
}

\author{
Dieter Karl DIEHL*
}

\begin{abstract}
As the 20th Century was remarkably shaped by the making and breakdown of socialism, the decisive role of $M$. Gorbatchev is set out and paid due tribute to him. In the absence of adequate statistical evidence proper, the article resorts to geopolitical argumentation and categorization in winners and loosers. As these geopolitical considerations are too broad, emphasis is placed on the few issues arsing from the $M$. Gorbatchev policies, the benefit to the West and NATO plus the future role of Turkey in particular while stressing the need for regional cooperation in order to reap many benefits which did and do come from the changed global framework.
\end{abstract}

\section{Understanding the Setting}

Between 1917 and 1950 countries containing one-third of the global population discontinued the market economy and started out on an experiment in constructing an alternative economic system: socialism. This happened first in the former Russian Empire and Mongolia. After the Second World War, in Central and Eastern Europe, the Baltic States, and subsequently China, Northern Korea, Vietnam, and after the Bandung Conference in 1955 the newly independent nations which wanted to stay outside the trading, investment and control grip of the former colonial powers assumed the role of socialist offshoots and imitators like India, Sri Lanka, Cuba, Angola, Mozambique, Tansania, Ethopia, Cap Verde Islands, Aden, Laos and Cambodia with vigorous "socialist concepts" - export drives in Latin America. It was a rather common feature of all that massive efforts were made to centralize control of production and allocate all resources through a system of state planning through a powerful bureaucracy.

\footnotetext{
"Professor, Nürtingen University of Applied Sciences, Germany.

[ASEANDIEHL@compuserve.com]
} 
There is no doubt that this vast socialist experimenttransformed the political and economic map of the world and set the courses for much of the 20th century.

Its failure has triggered off developments and motions just as radical a transformation, as these same countries change course, seeking to introduce some kind of market system and reintegrate into their regional and world economy.

The fact that so much remains to be done, makes it all the more important to study the main forces at work and deduce the key lessons of shaping the future world:

Karl Marx postulated that socialism would replace capitalism first in the labourintensive capitalist countries. The first part of the 20th century was a period of considerable movements and social fights and achievements, notably in the industrialized Europe. However, revolutionary socialism took hold in more agrarian states by emphasizing economic development and industrial advancement together with equitable distribution of the economic outputs. The success story covered increased outputs, dynamic drives of industrialization, the employment, infrastructual services and a seeming imperviousness to the Great Depression in the 30 ties that deeply hit the industrialized West and the USA.

Although incomes in socialist system were relatively evenly distributed, and an extensive welfare system ensured everyone access to education and health care, and retirement schemes, the socialist system as such was less stable than it presented itself to the outside world: planners build up an enormous bureaucracy to tap as much information as possible in order to avoid price-building in the market economy. Consequently, inside the planning process, planning became a personalized bargaining process with connections an important element: not the most modern technique was applied to increase efficiency, but the one which was regarded to save the benefits to those involved directly while advertising "modern" applications that did not hurt at all!

Such a built-in structure of connections proved to be bad for industrial advancement, but much worse for agriculture. Rather disincentives were coming along the operations and where individual incentives were required for strategic planning, an intrusive set of controls at all levels of decision-making hampered the continual modernization and customer orientation in production policies. At the beginning of socialism these may have been founded on ideological commitment of all parties involved plus a dedicated vanguard party, but sooner or later this resulted in cults of personality and abuses of position by nomenklatura elites. 
Heavy industry was overemphasized while light industries (consumer industries) put out high yields but low quality products. Official estimates draw the following picture: in the 1950 growth of output recorded an average rate of about $10 \%$ but this rate fell to about $7 \%$ in the 60 ties. The oilprice hike in the 70 ties helped the Soviet Union to much needed foreign exchange, but serious bottlenecks in production and deteriorating quality of manufactured output marked a controversial state to the output-oriented socialist statistics plus a spurt in corruption and enthusiastic but unrealistic ereporting.

Neither the Great Leap Forward in Communist China nor its Cultural Revolution cleared off the socialist structural deficiencies but left the whole society exhausted with politics and economic hardship. The farer distant to the center of political decisionmaking a few regions began to experiment with local reforms thus creating a base for "black-market operations" as the front-runner to a market system anyway.

In a stage of practically total isolation of the socialist block, firmly ambedded in the East-West confrontation, economic shortcomings and a system ridden with corruption, Mikhail Gorbatchev surprised the 27th Congress of the Central Committee with "Glasnost" and proposed a plan to "democratize" the Party Candidate Selection system. It was designed to bring the best to the decision-making structure while in doing so the "society is being changed" to responable, self-controlled, and wise allocation of local and regional resources. "Perestroika" stands for structural changes in society that enhance the efficiency of the economy through labour-incentives, decision-making at the business levels, and introduction of market element.

Soviet foreign policies so far, after a long series of "confidence building conferences ${ }^{3^{3}}$, showed also new approaches. The irony of history has it: a Soviet system that proved to be an alternative to capitalism really surprises the capitalist countries with a srong wish to end the are of confrontation known as "Cold War Period" and design a system of global peace and non-disrimination of sovereignity, and, and being set on joint efforts to further advance human welfare ${ }^{4}$.

The vision of international cooperation proposed by M. Gorbatchev were met rather with distrust and reserve. The US President R. Reagan mused about the "center of evil" and relucantly set on $\mathrm{SALT}^{5}$. M. Gorbatchev emphasized a bit later ${ }^{6}$ that a" global agreement" on the ban of nuclear armaments has to be taken into account. Furthermore, he advances the idea of "the Common European House"

Michel Fouché ${ }^{8}$ expertly sets out the making and also the mostly domestically addressed implications of this Greater Europe. With new governments to be quickly 
installed in the Baltic States, Chzechoslavia, Hungary, Poland, and fall of the communist rule in Roumania and Bulgaria, the soviet "hardliners" as opposing the quick developments, had to be hooked to the European House project.

It took two more summits with R. Reagan, after the Soviet Party Secretary's intensive talks with $\mathrm{M}$. Thatcher, UK Prime Minister, in London, to arrive at the first genuine arms reduction accord on elimination of medium-range nuclear missiles and ban on nuclear weapons to be again discussed by the fourth Summit scheduled for autumn 1988.

In retrospective, it emerges that during a time of dramatic changes in the socialist block notably USSR, the visionary counterparts in the West were rather absent: Reagonomics produced the biggest deficit story whatsoever and foreign policies never were a special favourite of him at all. The cohabitation in France limited the policy strategies for François Mitterand and M. Thatcher was in the wake of loosing political control over her Conservative Party while Dr. H. Kohl, the German Chancellor, had little choice in selecting a rather incompetent Foreign Minister then.

Consequently, much more could have been worked out with such a daring visionary as the Soviet Party Secretary, but there was practically no Western politician to emerge as a leading visionary and counterpart ${ }^{9}$ as well although Europe gained the most out of an imagined "Peace Dividend". end of tensions, German reunification, reduction in troupes, budgetary reductions in military spending, and a new spirit in Europe-wide cooperation with close Germany-Russia links.

The effects of "Glasnost" and "Perestroka" were increasingly. felt in Soviet Central Asia during 1989 while those of countries that followed the "socialist guidelines and framework" subsequently sensed the coming end of the "socialist value system in politics and business sector". It was the then Mexican President who complained about having lost the impressive "socialist orientation" while doubting that some compensation could be found so quickly (1989).

Simultaneously, after M. Gorbatchev's visit to the Vatican ${ }^{10}$, open debate on political, cultural, and religious issues were conducted and eagerly dealt with in journals and newspapers as they had not been since Stalin's consolidation of power. The more liberal policies introduced the more were they also accompanied by a sudden increase in ethnic and national awareness, and so, communal violence started and developed into a sort of ethnic clashes that gave way to political power struggles (Caucasian clashes, Tajikistan, Uzbekistan, Kazakhstan fights). 
The latest period of socialist policies in the traditional sense is represented by selected key variables for the period of 1965 to 1988 (Table 1) ${ }^{11}$. Taking the index of food production as a key variable, the only exception in an increase over the period of time under consideration attributes to Mongolia that really recorded a substantial drop in the provision of food. The daily calories supply per capita followed suite. This reflects the development of food production but indicates a level that is still beyond the poorest group of developing countries. The dependency on ODA ${ }^{12}$ and other assistance from outside plus the proportion of defence spending as \% of the GDP are equally illustrative (Table 2) for the post-Gorbatchev period.

\section{The Geographical Dimension and Some Economic Consequences of Glasnost and Perestroika}

Given the enormous difficulties in the Socialist Block and COMECON $^{13}$ (in particular with the founding members Soviet Union, Bulgaria, Poland, Roumania, Hungry, and Chzechoslavia). In 1950 joined the former German Democratic Republic, Mongalia in 1962, Cuba 1972, Vietnam 1978. Albania withdrew from the Council in 1962, and Yugoslavia had an Associated Membership Status. In the 80ties an observer Status had been granted to Afghanistan, Ethiopia, Angola, Laos, Mozambique, the People's Republic of Yemen, and Nicaragua.

Although China was not admitted to the COMECON, the first diplomatic mission brought the Party Secretary M. Gorbatchev to beijing ${ }^{14}$ where the long looming differences between these two socialist nations were on the agenda. Apart from achieving a relatively large agreement in the political arena, the major gain for the Chinese consisted in a large military assistance package with tanks and naval ships. This resulted in a much needed modernization of the military industrial complex and the building up of a considerable navy power in the chinese Seas. ${ }^{15}$

The German Mission paved eventually the way for German Unity in $1990^{16}$ with the accession of the former GDR ${ }^{17}$. That ushered in a completely new political framework in Europe while through this challenge and perspectives arising herefrom, the European Union achieved quite some dynamics and told all those American journalists that the "Eurosklerosis" has been a downrating term of the Reagan Era ${ }^{18}$ : high-rising US Dollar associated with a tremendous budget deficit and a balance of payment (balance of trade in particular) deep in the red, outflow of US capital to effect mergers and acquisitionsround the Globe ${ }^{19}$, and a rundown US infrastructure). 
Table 1

Selected Key Variables for the Socialist Block 1965-1988

\begin{tabular}{|c|c|c|c|c|c|c|c|c|c|c|c|c|c|c|c|c|}
\hline & \multicolumn{2}{|c|}{$\begin{array}{l}P \\
0 \\
p \\
u \\
1 \\
a \\
t \\
1 \\
0 \\
n\end{array}$} & \multicolumn{2}{|c|}{$\begin{array}{l}\text { U } \\
\text { r } \\
b \\
a \\
n \\
p \\
0 \\
p \\
.\end{array}$} & \multicolumn{2}{|c|}{$\begin{array}{l}\mathrm{L} \\
\mathrm{i} \\
\mathrm{f} \\
\mathrm{e} \\
\mathrm{e} \\
\mathrm{x} \\
\mathrm{p} \\
\mathrm{e} \\
\mathrm{c} \\
\mathrm{t} \\
.\end{array}$} & \multicolumn{2}{|c|}{$\begin{array}{l}\text { C } \\
0 \\
n \\
s \\
\dot{P} \\
0 \\
p \\
\dot{g} \\
\dot{r} \\
w \\
t \\
h\end{array}$} & \multicolumn{2}{|c|}{$\begin{array}{c}\text { D } \\
\mathrm{a} \\
\mathrm{I} \\
\mathrm{I} \\
\mathrm{y} \\
\mathrm{c} \\
\mathrm{a} \\
\mathrm{I} \\
0 \\
\mathrm{i} \\
\mathrm{i} \\
\mathrm{e} \\
\mathrm{s}\end{array}$} & \multicolumn{2}{|c|}{$\begin{array}{l}1 \\
x\end{array}$} & \multicolumn{2}{|c|}{$\begin{array}{l}\mathrm{L} \\
\mathrm{a} \\
\mathrm{n} \\
\mathrm{d}\end{array}$} & \multicolumn{2}{|c|}{$\begin{array}{c}p \\
o \\
p \\
u \\
1 \\
a \\
t \\
i \\
0 \\
n \\
(000 s)\end{array}$} \\
\hline \multirow{2}{*}{ States } & Mio & Mio & $\%$ & $\%$ & Years & Years & $\%$ & $\%$ & calor. & calor. & $\%$ & $\%$ & I.T. & I.T. & Mio & Mio \\
\hline & 1965 & 1988 & 1965 & 1988 & 1965 & 1988 & 1965 & 1988 & 1965 & 1988 & 1965 & 1988 & 1965 & 1988 & 1965 & 1988 \\
\hline USSR & 232 & 286 & 52 & 67 & 69 & 70 & 2,5 & 2,4 & 3205 & 3399 & 85 & 111 & & 22402 & & 307 \\
\hline Albania & 2 & 3 & 32 & 35 & 66 & 72 & 5,4 & 3,1 & 2389 & 2713 & 85 & 95 & & 29 & & 4 \\
\hline Bulgaria & 8 & 9 & 46 & 69 & 69 & 72 & 2,1 & 1,9 & 3452 & 3642 & 78 & 102 & & 111 & & 8 \\
\hline Chzechoslavia & 14 & 16 & 51 & 67 & 69 & 71 & 2,4 & 2 & 3383 & 3448 & 73 & 119 & & 128 & & 16 \\
\hline Cuba & 8 & 10 & 58 & 74 & 67 & 76 & 4,4 & 1,9 & 2374 & 3124 & 81 & 103 & & 111 & & 12 \\
\hline Democr. Rep. Korea & 12 & 21 & 45 & 66 & 57 & 70 & 6,5 & 2,5 & 2329 & 3232 & 73 & 118 & & 121 & & 16 \\
\hline German Dem. Rep. & 17 & 17 & 66 & 73 & 70 & 73 & 2,5 & 1,8 & 3204 & 3814 & 73 & 118 & & 108 & & 16 \\
\hline Mongolia & 1 & 2 & 42 & 51 & 50 & 62 & 5,9 & 4,9 & 2597 & 2847 & 138 & 99 & 98 & 102 & & 3 \\
\hline Group-Total & 294 & 364 & & 502 & & 566 & & 20.5 & & & & & & 23112 & & 382 \\
\hline $\begin{array}{l}\text { Group-Average } \\
\text { (unweighted \& own }\end{array}$ & 37 & 46 & 49 & 63 & 65 & 71 & 3,96 & 2,56 & 2867 & 3277 & 86 & 108 & & & & \\
\hline
\end{tabular}

IBRD: World Development Report 1990, ps 276-277 
Table 2

Selected Socio-Economic Variables for the Former Socialist Sector 1996 ranked by $\mathrm{HDI}$

\begin{tabular}{|c|c|c|c|c|c|c|}
\hline & Type & HDI-96 & Real GDP/PPP & LabourF\%popul. & ODA93-Net\%GNP & Def. As \%94GDP \\
\hline Czech Republic & COMECON & 0872 & & & & \\
\hline Hungary & COMECON & 0.855 & & & & \\
\hline Latvia & COMECON & 0.82 & & & & \\
\hline Belarus & COMECON & 0.787 & & & & \\
\hline Bulgaria & COMECON & 0.773 & & & & \\
\hline Estonia & COMECON & 0.749 & & & & \\
\hline Algeria & Socialist orientat & 0.746 & 5570 & 28 & 0.9 & 2.7 \\
\hline Kazakhstan & COMECON & 0.74 & & & & \\
\hline Cuba & COMECON & 0.726 & & 45 & & 2.7 \\
\hline Lithuania & COMECON & 0.719 & & & & \\
\hline Korea Dem. Rep. & COMECON & 0.714 & & 50 & (.) & 26.6 \\
\hline Armenia & COMECON & 0.68 & & & & \\
\hline Azerbeijan & COMECON & 0.665 & 2190 & & & \\
\hline Kyrgyz Republic & COMECON & 0.663 & 2320 & & & \\
\hline Georgia & COMECON & 0.645 & 1750 & & & \\
\hline Albania & COMECON & 0.633 & & & & \\
\hline Iraq & Socialist onientat & 0.599 & 3413 & 26 & 1.3 & 14.6 \\
\hline Cape Verde & Socialist orientat & 0.539 & 1820 & 37 & & 0.9 \\
\hline Dem. Apt. of Congo & Socialist orientat & 0.517 & & & 15.6 & \\
\hline India & Socialist orientał & 0.436 & 1240 & 43 & & 2.8 \\
\hline Lao PDR & COMECON & 0.4 & 1458 & 50 & 16.8 & 7.9 \\
\hline Guinea-Bissau & Socialist orientat & 0.297 & 860 & & 76 & 3.3 \\
\hline Angola & Socialist orientat & 0.283 & & & 01 & 8.7 \\
\hline Ethiopia & Socialist orientat & 0.237 & 420 & 44 & 17.2 & 2.6 \\
\hline Afghanistan & COMECON & 0.229 & & 41 & 3.9 & \\
\hline Bosnia \& Herzg. & Socialist orientat & & & & & \\
\hline Croatia & Socialist orientat & & & & & \\
\hline Fromer Yog. Maz. & Socialist orientat & & & & & \\
\hline Slovak Republic & COMECON & 0.864 & & & & \\
\hline Poland & COMECON & 0.819 & & & 0.9 & \\
\hline Russian Federat. & COMECON & 0.804 & & & & \\
\hline Romania & COMECON & 0.738 & & & & \\
\hline Ukraine & COMECON & 0.719 & & & & \\
\hline Turkmenistan & COMECON & 0.695 & & & & \\
\hline Uzbekistan & COMECON & 0.679 & & & & \\
\hline Moldava & COMECON & 0.663 & 2370 & & & \\
\hline Tajijisistan & COMECON & 0.616 & 1380 & & & \\
\hline Mongolia & COMECON & 0.576 & & 47 & 19.5 & 2.8 \\
\hline Nicaragua & Socialist orientat & 0.568 & 2280 & & 42.2 & 2 \\
\hline Vietnam & COMECON & 0.523 & 1040 & 51 & 7.5 & 5.7 \\
\hline Sao Tome\&Pr. & Socialist onientat & 0.458 & & & 124.4 & \\
\hline Myanmar & Socialist orientat & 0.451 & 650 & 51 & (.) & 3.1 \\
\hline Yemen Rep. & Socialist orientat & 0.366 & & 30 & 2.5 & 5.2 \\
\hline Tanzania & Socialist orientat & 0.364 & & 52 & 38.4 & 3.5 \\
\hline Mozambique & Socialist orientat & 0.261 & & 53 & 89.5 & 7.1 \\
\hline Yugoslavia : Serbia & Socialist orientat & & & & & \\
\hline Sources & & Table 1 ps165-167 & $\begin{array}{c}\text { Table } 4 \text { ps } 174-175 \\
\text { Table } 36 / 228 / 9\end{array}$ & Table 16 198-199 & Table 18, 202/3 & Table 19/204/5 \\
\hline
\end{tabular}

\begin{tabular}{|c|c|c|c|c|c|}
\hline & \multicolumn{2}{|c|}{ HDI-Properties : } & Highest HDI & Canadia & 0,901 \\
\hline & \multicolumn{2}{|c|}{ Tabl 1,ps 166 and 168} & Lowest HDI & Niger & 0,204 \\
\hline & & & & Germany & 0.920 \\
\hline \multicolumn{2}{|c|}{ Categories of Human Development } & & & Turkey & 0.711 \\
\hline Table 1.5, ps, 21 & HDI-1968 & HDI-1970 & HDF-1980 & HDl-1983 & \\
\hline $\begin{array}{l}\text { medium human development } \\
\text { low human development }\end{array}$ & $\begin{array}{l}0.659 \\
0.247\end{array}$ & $\begin{array}{l}0.599 \\
0.313\end{array}$ & $\begin{array}{l}0.659 \\
0.375\end{array}$ & 0.807 & \\
\hline
\end{tabular}


The Baltic States ${ }^{20}$ were quick in advancing their legal claim that they were never lawfully integrated into the Soviet Union. Poland was invited to join the agreement on the German Unity, while Hungary provided the substantial help in letting the East Germans flee to Western Germany. Against that it is quite understandable that Germany, France and Britain pressed for the process of accession as to bring in new members into the European Union. Thus the creation of a wider European House absorbed the diplomatic and decisionmaking levels throughout Europe.

The Cuban Mission proved to be a remarkable point in this diplomatic process. Against the direct budget assistance and military and energy aid granted by the Soviet Union, hard discussions on the world-market terms of energy provision and withholding of financial resources produced a rather quick end of the Angolan military adventure of Cuba, and, a little bit later the reassessing of the Mozambique, Ethiopia, Yemen, Vietnam, Laos, and Nicaragua ${ }^{21}$ involvement as well. Although most of containing of civil war in Southeast Africa must be attributed to the change in the South African leadership from LeClerk to Nelson Mandela.

Yasir Arafat's official visit to the USSR Party Secretary brought about a resolution on the recoginition of the State of Israel and constituted thus a vital mark on the road to furher negotiations on the Palestine issue ${ }^{22}$.

What are the consequences looking like for global considerations?

Judged from a contemporary level as measured by the Worldbank's Classification Criteria $^{23}$ and using the sheer number of states involved to categorize (see Table 3 ), out of 47 former socialist countries about half of them belong to the "low income group". About one third of them are concentrated in the Eastern Europe and Central Asia region. This is also true of those "transition or reform socities" which have been grouped as "middle income members" but in the lower sub-group (12 states).

The "middle income group, upper category" was reserved for 7 countries. Apart from the Libyan categorization, the Central European Members dispose of quite favourable endowments and education what makes them interesting to the European Union. The Worldbank Annual Report 1998/99 took 1989 as an index base and arrives at the period 1989-1996 that the former Soviet Union halfed its national production, whereas Belarus recorded about $55 \%$, Estonia $72 \%$, Latvia $58 \%$, Lithuania $48 \%$, and Ukraine the lowest level with $45 \%$, of 1989 -level ${ }^{24}$.

Making use of the Humman Development Index as developed by the Nobel Prize Winner of 1998, Prof. A. Sen, the socio-economic differences among the "socialistoriented and COMECON proper Members" (Observer Status covered as well), it is illustrated equally by the Table 2 that it still remains to be done a lot in order to improve the living conditions in these countries listed there. 


\section{The Geopolitical Loosers}

Talking about continents, it is hard to say but just the case: Africa, with the exception of South Africa and a few West African countries as well, did no longer qualify for further or close attention. Strangled by political dictatorships and epidemics plus civil wars geopolitical emphasis shifted to Europe and Asia. The latter standingfor the growth region ASEAN and the East Asian Economic Miracle ${ }^{25}$.

Talking about African countries, recall the developing countries sitting on the Council of Mutal Assitance: Angola, Mozambique, Ethopia, Yemen. But in 1999 Somalia, Sudan, Eritrea, and Liberia, Sierra Leone, and Zaire still have to struggle longer for peace and political consolidation!

Looking at Latin American and Middle America in particular, Cuba did loose also a helping hand and a considerable economic assistance from the COMECON that recorded also on April 17, 1990 an outstanding trading gap amounting to 15 bill. of Rubles (about 1:1 US Dollar then). Energy supplied had to be priced immediately at market quotations, increases in trade became crucial for Cuba: the Agreement envisaged an increase in Cuban exportations to the USSR, and included for the first time high-tech medical instruments and medicines in exchange for wheat and warplanes (MIG 29). In addition to that, Cuba changed the trading partner rather radically and went for more intensive trade with China ${ }^{26}$. Politically, an end was also put to the "Angola Commitment" with the execution of the former chief of staff in Angola, Arnaldo Ochoa, and 3 officers from the Ministry of the Interior ${ }^{27}$.

So did Nicaragua and al the Latin American movements looking for a socialist type of future society. As far as the Carribics and the adjacent states are concerned, there is a growing awareness that common or joint efforts together with the former or still considering itself as socialist nation should be promoted within the regional context. Apart from the political arrangements achieved ${ }^{28}$, the emphasis is surely on CARICOM, ECCM, OECS, and CARIFTA ${ }^{29}$ if still applicable by operational standards and perspectives ${ }^{30}$.

India with her long-standing socialist relationship with the Soviet Union and COMECON is surely on the short hand of loosing: large Rupiah, non-convertible credit balances rest with Russian and Indian banks. All the Indian efforts to withdraw them in convertible currencies failed as the debtors could not make available foreign exchange resources. Talks had been held that fill meters of files, but with no striking success so far. 
Table 3

Classification of Reform Economies by Income \& Region 1998

Compilation by IBRD Report 1998/99

\begin{tabular}{|c|c|c|c|c|c|c|c|}
\hline Group & $\begin{array}{c}\text { East \& } \\
\text { Southern Africa }\end{array}$ & West Africa & $\begin{array}{l}\text { East Asia } \\
\text { \& Pacific }\end{array}$ & $\begin{array}{l}\text { South } \\
\text { Asia }\end{array}$ & $\begin{array}{c}\text { Eastern E. } \\
\text { \& Central \& } \\
\text { East Asia } \\
\end{array}$ & $\begin{array}{c}\text { Middle } \\
\text { East \& } \\
\text { North Africa } \\
\end{array}$ & Americas \\
\hline $\begin{array}{l}\text { Low } \\
\text { Income } \\
\text { Group }\end{array}$ & $\begin{array}{l}\text { Angola } \\
\text { Dem. Rp. of Congo } \\
\text { Ethiopia } \\
\text { Mozambique } \\
\text { Tanzania }\end{array}$ & $\begin{array}{l}\text { Guinea-Bissau } \\
\text { Sao Tome \& Pr. }\end{array}$ & $\begin{array}{l}\text { Lao PDR } \\
\text { Mongolia } \\
\text { Myanmar } \\
\text { Vietnam }\end{array}$ & $\begin{array}{l}\text { Aighanistan } \\
\text { India }\end{array}$ & $\begin{array}{l}\text { Albania } \\
\text { Armenia } \\
\text { Azerbaijan } \\
\text { Bosnia \& Herzg. } \\
\text { Kygyz Republic } \\
\text { Moldava } \\
\text { Tajikistan } \\
\text { Turkmenistan }\end{array}$ & Yemen Rep. & Nicaragua \\
\hline $\begin{array}{l}\text { Middle Incorme } \\
\text { Group } \\
\text { lower subgroup }\end{array}$ & & Cape Verde & Korea Dem. Rep. & & $\begin{array}{l}\text { Belarus } \\
\text { Bulgaria } \\
\text { Georgia } \\
\text { Kazakhstan } \\
\text { Latvia } \\
\text { Lithuania } \\
\text { Former Yog. Maz. } \\
\text { Romania } \\
\text { Russian Federat. } \\
\text { Ukraine } \\
\text { Uzbekistan } \\
\text { Yugoslavia:Serbia } \\
\end{array}$ & $\begin{array}{l}\text { Algeria } \\
\text { Iraq }\end{array}$ & Cuba \\
\hline $\begin{array}{l}\text { Middle Incorme } \\
\text { Group } \\
\text { Upper subgroup }\end{array}$ & & & & & $\begin{array}{l}\text { Croatia } \\
\text { Czech Republic } \\
\text { Estonia } \\
\text { Hungary } \\
\text { Poland } \\
\text { Slovak Republic }\end{array}$ & Libya & \\
\hline Number of states & 5 & 3 & 5 & 2 & 26 & 4 & 2 \\
\hline
\end{tabular}

IBRD: World Development Report 1998, ps.250-251 
Two aspects are significant: first, the growing trade with Russia and COMECON members showed the increasing quality and larger export potential of India, and, thus, should be honoured for succesfully restructuring its quality and export performance. Secondly, the Western creditors who are also directly or indirectly committed to development aid to India should rethink their financial position to that end that they could help Russia and India at the same time: helping with credits to $\mathrm{CIS}^{31}$ in order to put them into a position of serving the CIS-India outstanding balances.

India's military hardware is mostly Russian which happens to be nowadays Ukrainean Providers mostly. They are also manufactured in India under CIS-licence, and, thus, providing a long-term perspective of sales. However, this fact might be used as a lever to push the unresolved Rupiah-Rubel balance issues towards an acceptable solution.

As China, North Korea, Cuba and Vietnam flatly rejected the "glasnost" and "perestroika" the pressures arising from domestic and external issues were particularly obvious. Apart from a negotiating outstanding COMECON balances, trade and investment plus political reorientation proved to be most time-consuming and adding more impetus to centrifugal forces already in place to a certain extent.

A striking example is Vietnam by being suddenly confronted with taking back a large group of Vietnamese immigrant workers to the USSR and other former socialist countries. Those Vietnamese groups that stayed in Eastern Germany and Russia constituted almost $4 / 5$ of those living abroad ${ }^{32}$. While those from Russian engagements were most welcome home but the East German ones were refused by the Vietnamese Government because of their fresh and vivid experiences with the breakdown of German socialism and building up of pluralistic structures! In the meanwhile Vietnam's policy reforms boosted economic growth even before external aid was flowing in. Furthermore, since 1989 national productivity ever increased and thus, the Vietnamese economy stands out of the group of former socialist economies ${ }^{33}$.

Looking at the Near East, it is obvious that the end of the "Cold War" produced its special impact as well. The Israelian Government realizes nowadays increasingly that there is not much room left for not arriving at a progressive pacification. But the Iraki President illustrated clearly that the breakdown of the socialist system produced also some vacuum that can be filled with national policies, military actions, cunning attitudes applauded by the Arab world. Against that one is tempted to say that the end 
of the Cold War helped Saddam Hussein to stay longer in power, and, this could be considered as a winner of the diplomatic game after the Gorbatchev Era.

A similar geopolitical role must be attributed to Turkey. ever seen as a NATO stronghold and listening post to the Soviet and Near East air traffick, the end of the Russia-Europe confrontation weakened the geopolitical role of the Turk Republic. No longer it appeared to be necessary for the Turkish Government to buy modern US warfare and defence materials, but the NVA ${ }^{34}$-tanks ${ }^{35}$ sold off by the united Germany in $1991^{36}$ ! This incidence provides sufficient evidence on how the "Gorbatchev Bang" produced not only an international irritation but also translated some Turkish domestic and foreign policy issues.

Talking about supranational institutions the breakdown of socialism had a tremendous effect on the global decision-making machinery: the UNCTAD ${ }^{37}$ once the front-runner of the Non-Alligned Members ${ }^{38}$ did falter after the first oil price hike in the early 70ties what set an end to the to the efficient and efective leadership of Indian diplomacy. The oil price shock resulted in more bilateralism than multilateral decisionmaking. This is quite understandable as most outstanding debts of developing countries demanded discussions with the creditor nations. In addition, Reagonomics and Thatcherism did not honour their fee commitments to the United Nations Group. A dwindling resource base could not be brought in line with the additional challenges arising from Cambodia to Somalia and Sudan missions plus the breakdown of Yugoslavia.

A way out of this dilemma proved to be very long and time-consuming: establishing a transparent and accountable recording plus accounting proper system throughout the UNO-Family Institutions! As this did not produce quick and sweeping results, United Nations Policies limit actions to those which can be funded by respective Member States. This was clearly illustrated by the "Dessert War" against Irak where the defence forces were backed by a UN mandate. However, the punishment raid by late December 1998, the UK and the USA did not need and take any backing from the UNO Security Council. By doing so, it was clearly made obvious that the UN is no longer treated as a supranational decision-making body while Russia is firmly imbedded in internal affairs and a broken-down economy. Since the superpowers in the World do not need anymore the UNO Meetings to display their differing views, the Meetings are less interesting to the financially rather weelendowed members. But still an organization wanted badly by the former socialist economies and developing countries.

UNO Reform reflections have been made to concentrate on major organizations such as the Economic and Social Council and UNDP ${ }^{39}$ while funding a new network 
structure is not very popular among the current Members of the UNO Group. As a function of the willingness to financially support the UN Security Council and the other Special Organizations, the accession of new states enlarged the demand for assistance, but rarely broadened financially the base of the UNO Family! More close and systematic research has to be done in order to set up a clear balance of developments since 1985.

\section{A Few Geopolitical Winners}

For operational purposes the WTO ${ }^{40}$ is considered to be helpful for trade and investment disputes, and, against the dilemma with global arrangements, is very happy about regional cooperation that brings together exporting, importing and investment interest along the lines of WTO - objectives.

At the time of the "Bang" there was not much to worry anymore about the UNCTAD situation. The more so, as after the end of the East-West confrontation the budget problem for the UNO-Group emerged as a crucial issue.

Thus, the $W M O^{41}, F A O^{42}, W M O^{43}, W I P O^{44}$, to name a few of the 55 special organizations of the UNO-Group ${ }^{45}$, changed their membership structure remarkably and enlarged it as well by new government representatives, the funds for operations not necessarily expanded with the growth in seats and well-designed project applications.

The World Bank or International Bank for Reconstruction and Development (IBRD) together with the International Monetary Fund (IMF) benefited from the new memberships and could broaden their country-base respectively. The only countries still staying outside of the operations of the two "Bretton-Wood Institutions" ${ }^{46}$ is Cuba and North Korea.

The UN Economic Commission for Europe (known as ECE) had suddenly to realize the inflowing demand of new nations after the breakdown that were eager to take advice and any assistance avaible for them from the UNO-Family. Measured in demand for services the UN Social and Economic Councif ${ }^{47}$ and UNDP were among those who saw themselves confronted with a rising demand for services, but organizational and financial limitations hampered expanded functions and any corresponding to pressing and urgent needs.

Another UNO-Winner is the $I T U^{48}$. Dynamic and strategic alliances of telecommunication corporations round the globe ${ }^{49}$ push for acceptable technical 
interchange and cooperation standards. It appears that the ITU had boarded this fast running train in order to safeguard global standards to benefit consumers. Again future national and regional interests induce monitoring and watching of further developments.

The NATO was immediately approached by new membership applications what put the political organization called the $\mathrm{WEU}^{50}$ to look into the scheduling of democratic procedures in all applying countries.

With new members admitted to the OECD, the Club of Industrialized Countries ${ }^{51}$, this organization got immediately involved in designing the national accounting and other standards for the member states. It was therefore quite understandable that the first studies undertaken in Russia were joint efforts together with the Worldbank and the International Monetary Fund ${ }^{52}$.

\section{Europe gained most of the benefits: politically and institutionally!}

The frontiers in Europe were redressed and Germany united. Additionally, after military withdrawals of Russian troups, the newly elected governments were set on participating in the construction of the European House without being still threatened by the former Soviet Regime. This gave enough room for negotiating new neighbourly relations and forming new regional cooperation zone as a first step to the integration (see Central Europe Economic Cooperation) into the European Union.

This new European Framework plus the interest of former socialist countries to expect financial and technical assistance from Europe helped to pave the way for a sort of "global telecommunication network". Certainly, the dynamic growth and development in telecommunication technology had its dynamic from a formidable research infrastructure outside of the Gorbatchev Bang, of course. It is this technology which will shape the future of all states on the globe whether repressive governments want it or not! ${ }^{53}$.

Institutionally, the European Bank for Reconstruction and Development was set up, following a Frensh initiative (1989) to raise the funds needed for the immense financing requirements of states willing to restructure their economies. The statistical work and publications by the London-based Bank such as "Transition Reports" do represent a very valuable source for further research and documentation.

Equally, the European Union quickly designed $T A C I S^{54}$ programes after some other like PHARE in order to provide technical expertise in infrastructural and banking areas. 
Also Europe benefitted from the establishment of the EBRD, London. The TACIS country profiles also provide a relatively formidable and dependable statistical base. This will guarantee an important future role in any research project to be undertaken! This is associated with a further concentration on Europe's attractiveness.

The African-Carribean-Pacific Convention, short: Lomé Convention, was suddenly enjoying the new political framework as well and could count on a closer cooperation with the old, but socialist or communist members. It can be expected that this Convention agreed upon in 1975 can only benefit further through restructuring rather radically itself. The current phase of the Lomé Convention is characterized by rethinking its future role and what financial frame is necessary to really have an impact on the development of the whole ACP-zone. From that it really depends whether the "model for cooperation between industrialized and developing countires" can live up to this reputation! A little bit later, the EU was pushed to realize that the geopolitical flank of the Mediterranean space would deserve a new approach ${ }^{55}$ towards a regional partnership that breaks with the past "bilateralism" in the Mediterranean! This comes under new "Policy Coherence"!

Although the already very long standing application of Turkey to become a fullmember of the European Union appeared to be delayed further, the Turkish geopolitical situation was equally improved what may usher in a future-oriented strategy: the Caucausan fights for political control and geographical delineation issues enhanced again the importance of Turkey.

The Iraki policies helped as well to bring back to the decision-making lobby in Europe and USA the message that without the American airstrips in Turkey and the NATO hardware stocked there nothing could be done to press for an effective control over the Iraki territory.

However, the Turkish descent and traditions provide a perfect mix for the Turkish diplomats: all the Muslim nations emerging from the Soviet Union find a helpful link to Turkey and is business community:

From Azerbaidjan to Kasachstan Turkish businessmen are present to conduct their import-export bargaining to the benefit of international trade relations. These relations are not only important in terms of energy sourcing but also for precious metal and agricultural products. Creating the infrastructure in these nations is a challenge that invites numerous capitalists that can come from Germany as immigrant Turkish worker or nationalized German. Thus, the German-Turkey cooperation could open up 
new opportunities in these countries and this clearly opts for a closer relationship between Turkey and Germany as experienced nowadays.

This is emphasized by the fact that some of these Muslim nations are reflecting on reorientation their economic exchanges that were programmed under a centralized planning system directed by Moscow. Regional cooperation awareness ${ }^{56}$ is considerably growing and enormously challenged by pipeline planning and shipment routes. The Black Sea Economic Cooperation ${ }^{57}$ is one example, and the huge domestic port complex that will link the Kaspian Sea to the Wolga Channel System ${ }^{58}$. The Black Sea Trade and Development Bank is headquartered at Thessalonika and will certainly play a remarkable role in regional promotion. The American oil and natural gas explorers' plans to links the Kasachstan oil system with the Pakistani port of Karachi ${ }^{59}$ has to be mentioned as well. Furthermore, the Ukrainian Government fed up with the Russian way of handling controversial issues such as the Black Sea Fleet ${ }^{60}$ and energy supplies surely feels like a winner of the "Gorbatchev Bang" to that extent that security considerations were moulded in a cooperation agreement with the NATO Secretariat. This 1997 event to judge now is not easy as the long-term implications are difficult to assess.

For Europe and the NATO such an agreement illustrates successfully the political extension of controllable territory into the far East of Europe. Only the fact that the current Russian Government is preoccupied with its political survival can be attributed to the relatively low-key reaction for the time being. However, the role of the Russian military nowadays must not be the same in the future after the current President Jelzin. Strategic thinking along military and political line might be inclined to put this issue back on the agenda of bi- and multilateral talks of the future.

\section{Striking a Balance}

To strike a balance on the basis of the foregoing argumentation and period 19851993 is no easy task at all for various reasons.

- First, the time horizon of the analysis can not be limited to the past year 1998, and furthermore, some variables might prove to take a much longer period for materializing.

The statistical base is still a matter of concern although some good advances could be realized. 
- Secondly, the analysis over here does assess a selected number of known cases only, where evidence is available in English.

- Thirdly, the scale used must be rather ordinal than cardinal, thus, a clear numerical picture can not be achieved at all.

- This refers to the fourth problem: the analyses contains subjective valuations although it is attempted to make objective statements.

- Fitthly, some outcome of the Gorbatchev Missions is the starting point of irritations which can increase and even produce a serious problem: popping up the Chinese tank and naval ship fleet.

The fact is that since 1990 the ASEAN Member States and Vietnam have continuously increased their defence spending in order to make their role felt in the Spratly Island dispute. Located in the Vietnam-Chine-Philippine-Indonesia quadrant, with Vietnam originally dreaming of an oil bonanza with the first drills, and the former Indonesian President Suharto investing a considerable lump sum in the development of the Indonesia-claimed areas, the game for oil pumping is still on. The perspectives are not yet clear with one exception:

Mitsubishi as a late-coming explorator to the Spratly scene hit by chance the most productive source so far.

Against that that it is understandable that the Vietnamese Government pressed for an ASEAN Membership. The ASEAN-Group on their part were also eager to round off the zone of influence and to build up a countervailing power with a view to China. Current naval manoevers in the China Sea are quite intriguing to the ASEAN Community.

Almost regardless to the type of governance exerted by active and prospective ASEAN members, Myanmar has been admitted to ASEAN as well, and Cambodia and Laos are on the waiting list, politically, the zoning concept appears to be a solid approach, but should be backed by financial resources and military standards as well. The two latter points are of special attention: first, after the 1997-breakdown in Southeast Asia, the current economic situation is difficult to assess.

To overcome the rather big difficulties in bank management and supervision plus regulatory framework will absorb much more resources than made available by the International Monetary Fund. The Japanese Government is also offering financial 
support altnough its own on financial potential is much debated currently as well. But the Japenese involvement in ASEAN and Far East economies is large and constitutes a real headache.

This is not the situation to play the role of big defence spender at all. Thus, a lot more of diplomatic motions have to be staged to sort out issues. The task is not easy since the Chinese Navy is really making an irritating appearance in South Chinese Waters: unimportant, not inhabited islands north to the Spratly Islands are occupied and equipped with baracks. So still far of the Spratly track, this move can be understood as some military advancement through front-running settlements.

Together with the Taiwan-status issue and the South Korean-Japan troubles with some islands lying in between, the mixture of expectations and stubborn attitudes among politicians and military personnel can be the fermentation ground to further misunderstandings and harsh reactions and sudden actions.

Whether the Kurile Islands issue, M. Gorbatchev opened that long-guarded file also, is drawing nearer to a close under the current Russian Government can not be answered yet.

In a fundamentally European sense, the balance is positive measured by unification of Germany, more Middle and Central European nations interested in joining the European Union, the EURO providing the financial base and attraction for trading and investing in a larger economic zone ${ }^{61}$.

- Moreover, the market system as such could be exported to the Middle and Central European states, and that could open up new opportunities for busineses. And, with the Turkish partner the EU could benefit also from the more prominent Turkish role in the Black Sea, Caspian Sea and other Muslim economic commitment.

Looking through NATO glasses it is also advantageous to have an Ukranian partner as a front-post to any irritations in the relationships with Russia. But, due consideration has to be attributed to the future Russian Government and its military base.

The biggest outcome of the "Gorbatchev Bang" is that the system of market capitalism, which was developed in Europe first, has eventually become a sort of global instrument of economic development. The Far East and Southeast Asia plus India have demonstrated that they can marry capitalist institutions with vehicles of rapid economic growth. Today, the Western countries generate about $45 \%$ of World 
$\operatorname{GDP}^{62}$ with about a $13 \%$-share in total world population. Estimates calculate that during the next ten years the Asian income share could rise to $50 \%$ while the European one will reduce to about $30 \%$. Against that it would be good to monitor the development of the four largest Asian Countries-India, China, Indonesia- that cater for about $40 \%$ of world population. This should suffice to state that mobilizing the market forces in former socialist economies has to be pursued vigorously by encouraging Asia to rejoin a world economic system founded on commitments to the international rule of wise regulatory framework and rule of law, political and economic freedom plus opportunities for trade and investment by all countries that subscribe to shared and acceptable international norms.

\section{The Regionalization Option}

- First, a Long-standing experience with ancient empires and modern imperial realms hints that apart from self-reflections, all these "global" regimes existed as some sort of regional control. And, globally available political control devices require some local power play and legitimate acceptance in turn. All talking about "globalization" so favourite a topic to politicians throughout the world when it boils down to "constituencies" there is no way of escaping reality at all.

- Secondly, "think globally, work locally",63, but think about your neighbours also! The latter strictly opts for regionalization, and the NAFTA, APEC, EU/EURO Zone are formidable examples as also illustrated by the New Miyazawa Initiative ${ }^{64}$ that is backed by a US\$ 15 bill. in cash for short-term capital needs, mainly in the form of low-interest, yen-denomated loans, and another US\$15 bill. in the form of concessionary trade and investment over three years. The countries earmarked as recipients so far are Indonesia, Malaysia, the Philippines, Thailand, and South Korea.

It is very significant that this Japanese Initiative will be disbursed bilaterally to fend off criticism from the IMF and the USA: Japan is making moves to counteract the IMFinvolvement. But, Japanese officials make it very clear: "It is more important to secure the vitality of the regional markets to help revitalize our economy! $!^{65}$ By this YEN approach Japan will also succeed in expanding the YEN-Zone and reduces the importance of the US\$ with interesting the level of YEN securities.

- Thirdly, this gives due consideration to regionalization: for raising capital, mobilizing resources, supervision of procedures, sharing the burden of restructuring and benefits of a genuine regional cooperation ${ }^{66}$. Building the capacity and infrastructure for applied research is just the item to be entered on any priority agenda of decision-makers throughout the world that suffers from governments with budget deficits, high debt servicing ratios, and sometimes excessive taxing. 
- Fourthly, in the absence of crucial and far-sighted global decision-making structure, the UNO-Group must embark on the mobilization of resources and development opportunities of regional zones within the broader framework operated by the WTO.

- Fifthly, countervaling, lobby powers can only be craeted through joint efforts within or outside the given supranational framework.

- Sixthly, there is a marked change occuring in the way of an increasing number of policy markers viewing regional integration within the multilateral trading and investment system as further enhanced by the WTO. The situation so far can be characterized by a statement that there is a shift from "regionalism versus multilateralism" to "regionalism and multilaterialism". Consequently, the OECD - Workshop of July 1995 avoided to talk about the "globalization"

- Seventhly, regional initiatives increase the awareness of technical impediments to trade and investment and contribute so to an understanding of the disposable means by which they can be reduced or eliminated. However, there is a risk to set up new ones once a new regional framework has been set up. The EU and NAFTA are illustrative examples.

- Eightly, Experience from 25 years has it that those societies progressed which have mastered the acquisition of knowledge, increased the capacity to absorb and manage it, and improved the technology of communication between the citizens. Making available all respective resources within the regional context will certainly provide ways around information and market failures plus enlighten the lives in the region and everwhere

- And, eventually, regional decision-making is more flexible, and, thus more efficient and more representative than time-consuming global decision-taking procedures. At this level national interests can be safeguarded more easily as well. In doing so, a well-balanced and structured regional approach can help to improve global coordination. This appears to be also the vital lesson learned from the $A P E C^{68}$ that is based on conferences sponsored by APEC-Members in the absence of any institutional framework by pointing acidly to the rather "bureaucratic approach" (building of institutions) by the European Union.

These two approaches are competing models of integration. But both ways imply some regional harmonization and integration to be successful. Hence, once the issues are clear one could be tempted to refuse to handle, but through audacious and well-funded approaches we will be obliged to explore new objectives, new methods 
and efficient techniques to identify future problems and to solve them. It will keep us busy in a very reasonable way throughout the life of a social research worker within a regional context rather than a global one!

As it appears to be the "law of radical reforms" in mankind that never those daring personalities who took the crucial initiative can reap the benefits of their work within their active time, but the "sideliners" and "secondary jumpers to the scene" carry the victory, it is this article has been designed to give due credit to the genuine father of the "1988/89-Bang" In restoring the rightfully earned reputation it is an invitation to all reearchers from all regions to beat the "regional drum" in due consideration and exploitation of Mikhail Gorbatchev' visions and past, current, and future results.

\section{Endnotes}

1 January 27, 1987; the term stands for "publicity" in the sense of transparency and accountability!

2 July 15, 1987.

3 designed by the late Nobel Prize Winner and Chancellor of the Republic of Germany: Willy Brandt in the early 70 ties.

4 The full scope of cooperative efforts is illustrated by the official agreements concluded between the Soviet Union and the Republic of Germany; see: Dokumentation zur Ostpolitik der Bundesregierung, Verträge, Vereinbarungen und Erklärungen, herausgegeben vom Presse- und Informationsamt der Bundesregierung, Reihe: Berichte und Dokumentationen, 13. Auflage, 1990, ps. 21.

5 Strategic Arms Limitation Talks; Meeting at Reykjavik at Oct. 11-12, 1986, see also: L'Etat du Monde 1991, Paris: La Découverte, 1991, ps. 22.

6 Oct. 22, 1986: it has to be a global accord!

7 L'Etat du Monde 1991, Paris: La Découverte, 1991, ps. 30.

8 L'Insertion de l'URSS dans une "plus grande Europe", in: L'Etat du Monde 1991, Paris: La Découverte, 1991, ps. 31.

9 The london Conference of the G7 in July 1991 did not come up with some tangible results. See also B. Guetta: Ce que J'Ouest pouvait faire pour Gorbatchev, in: Létat du Monde 1992, ps. 31-33.

10 Dec. 1, 1989; the Vatican reacted quickly and called for a East-West meeting (Synode: Newj Envangelization) of religious representatives on Dec. 14, 1991.

11 There is no full coverage of the whole group of the COMECON because of availablity of data. This selection is taken from a Worldbank publication that complained about the "non- 
reporting states".

12 Official Development Assistance as defined by the Development Assistance Committee of the OECD (1960).

13 Council for Mutual Economic Assistance created as a competitive organization to the 1948OEEC (Organization for European Economic Cooperation), known popularly as "Marshall Plan institution" that handled the "European Recovery Programme" and paved the way to the European Community of 1967, Rome).

14

15 This fact will be discussed later again under the heading of "Negative Fallouts of $M$. Gorbatchev policies".

16 Not to forget about the "10-Item Declaration" designed by the former German Chancellor Dr. H. Kohl, who jumped at the unity proposition made in the Caucaus by M. Gorbatchev, but the secrecy applied irritated the former prime Minister M. Thatcher and Premier Ministry François Mitterand at the beginning of the "4-Partner Table Rounds" in 1989.

17 German Democratic Republic.

18 This refers to a mainstream theme disseminated by the "Times" and "Newsweek Magazines" in particular.

19 This development brought J. Naisbitt to the trend of "strategic alliances" of transnational companies; a recent article by J. Slater: Squeezing the Middlemen, Multinationals move in on Troubled Local Partners, in: FEER, Jan. 14, 199 , p. 70 illustrates that the following set of motives can be observed: multinationals take over a floundering intermediare, assume direct control of sales and marketing decisions, switch partners before the market will do, streamline production and service patterns.

20 Although M. Gorbatchev went personally to Lituania, but the Lituan Government declared its independence shortly thereafter: March 18, 1991 at Wilnius.

21 The San-José-de Costa-Rica Conference saw the peace-agreement between the Sandinistas and Contras on January 16,1988 and marked a "regional success" as Middle American States pushed for ending the conflict an given the influence away to foreign socialist or Cuban forces.

22 April 9, 1988.

23 See: World Development Report 1998, p.s 250 and 251, abstract by author.

24 IBRD: World Development Report 1998/99, Fig. 10.1, p. 155.

25 This refers to a publication of the Worldbank: The East Asian Miracle-Economic Growth and Public Policy, A Worldbank Policy Research Report, Oxford-New York-Toronto et. al.: Oxford. University Press, 1993.

26 Fidel Castro announced on Febr. 16, 1990 political and economic reforms!

27 See: L'état du Monde 1991, Paris: La Découverte, 1991, p. 398.

28 Achieving peace talks and a policy to contain trafficking 
29 For full coverage of regional efforts in regionalization of developing countries see: Akman, M. Sait and Dartan, M.: Regionalismin the World Economy: Novel Expectations from an Old Habit, in: Marmara Journal of European Studies, Vol. 6, No. 1, 1998, ps. 15.

30 Caribbean Common Market, Georgetown/Guayana; ECCM=East Caribbean Common Market; CARIFTA: Caribbean Free Trade Association; OECS: Organization of Eastern Caribbean States, St. Kitts.

31 Commonwealth of Independent States: Aetwork of former socialist member countries formed after the demission of soviet Party Secretary M. Gorbatchev in 1993.

32 Estimate based on newspaper articles in 1990.

33 IBRD: World Development Report 1998/99, Figure 9.1, ps. 136, 137.

34 Nationale Volksarmee-Panzer.

35 Nationale Volksarmee Panzer=GDR-Army tanks.

36 March 27, 1992: The delivery of NVA-tanks to Turqie are suspended and the German Minister of Defence Dr. G. Stoltenberg is replaced by Mr. V. Rühe.

37 United Nations Conference on Trade and Development set the $0,7 \%$-GDP official assistance objective in 1968 that is still accepted so far.

38 Formed in 1995 at Bandung/Indonesia.

39 United Nations Development Program: sponsor of the UNCTAD since 1964 and Human Development Report from 1990 onwards.

40 World Trade Organization, Geneva.

41 World Meteorological Organization, Geneva.

42 Food and Agriculture Organization, Rome.

43 United Nations Industrial Development Organization, Vienna, 1996.

44 World Intellectual Property Organization, New York.

45 To obtain recent Budget Data is stil incurring too much travel expenses!

46 Establishment of both in 1944 at a Resort in the USA.

47 Flooded with report from UN Organizations and hopelessly understaffed, the cry for quick reforms and increase in efficiency became louder! Reform reflections concentrated recently on making the Council and UNDP efficient and well-budgeted new Organizations.

48 International Telecommunication Union, Geneva.

49 This refers to the completion of the layer work of the Trans-Asia-Europe Optical Fibre on Oct. 19, 1998. Rhia Project could not have taken place earlier in socialist time at all:

covering 20 different states and $27000 \mathrm{~km}$ in length between Francfort/Main and Shanghai. Quoted from: World News, in: Communications Week International, Issue 213, Oct. 19, 1998, p. 4. 
50 West European Union, the club of European Democracies.

51 Turkey belongs to the founding group of members right from the start!.

52 This refers to "stocktaking" missions undertaken in the 90 ties.

$53 \mathrm{~A}$ full and accurate coverage on the most dynamic developments in telecommunication technologies is given by "Communications Week International", EMAP Readerlink, Middlesex, UK.

54 Technical Assistance to the Commonwealth of Independent States.

55 See the study undertaken under the programme "Globalisation and Independence: the Challenge of Policy Coherence", L. Fontagné, and N. Péridy: The EU and the Maghreb, Paris: OECD, 1997.

56 There was a conference held a Achkabad, Turkmenistan. Besides the Muslim successor states Iran, Turkey and Pakistan attended the Meeting, On May 10, 1992.

57 See particulary the article by M. Dartan on the setting perspectives of this organization.

58 The author proposed 1998 to establish a "watch group" at Marmara University on these plans what would help to graduation theses and dissertations. Their result would contribute to a systematic monitoring and policy formulating excercise.

591998 plans under discussion with Taliban representatives.

60 June 23, 1992, Agreement reached at Dagomys.

61 However, M. Feldstein cautions the readers of the Journal "Foreign Affairs: "EMU and International Conflict", in: Nov./Dec. 1997, vol. 76, No. 6, ps 60 etc.

62 Gross Domestic Product, an aggregate over all countries.

63 after John Naisbitt: The Global Paradox, 1994.

64 Dec. 1998 Initiative after the first proposal critized by the IMF, USA, EU for not being too realistic but rather ambitious.

65 Against a Japanese share of $40 \%$ in trade and about $20 \%$ in investment in ASEAN, it is understandable that the Far Eastern Economic Review correspondent quoted this statement. In: M. Vatikiotis and M. Hiebert: Help Yourself, in:FEER, Dec. 31, 98 and Jan. 7,1999, ps. 13.

66 A very good example is provided by the African Economic Research Consortium that rose from a sponsored small level (Canadian International Development Research Center, 1984) to a continent-wide organization that will shape the redressment of African situations immediately.

67 OECD : Regionalism and its Place in the Multilateral Trading System, in: OECD Documents, Paris: OECD, 1996.

68 Asian Pacific Economic Cooperation, first promoted by Australia and New Zealand in 1989 as a response to the European Union and Single Market move and the NAFTA agreement. 